\title{
Analysis of Existing Reform Proposals
}

Various scholars have addressed the issue of ICSID arbitrators' independence and impartiality since the beginning of this project. To the extent that they provide any explanation for their preoccupation with this topic at all, they predominantly very generically refer to the increasing number of arbitrator challenges in the past years, ${ }^{933}$ and to the resulting "discomfort" or "concern" regarding arbitrator independence and impartiality. ${ }^{934}$ Only a few scholars specify this observation and make assumptions as to the potential causes for the increase: The inadequacy of the relevant standard of independence and impartiality or a rise in uncalled-for dilatory challenges could be the source of the surge in arbitrator challenges, they surmise. ${ }^{935}$ Interestingly, scholars have only exceptionally broached the issue based on the belief that ICSID arbitration suffers from an acute and prevalent, systemic lack of independence and impartiality. ${ }^{936}$ Only very rarely did the impression of an irreconcilable conflict between independence and impartiality and systemic characteristics of investment arbitration motivate scholars' analysis of this subject. ${ }^{937}$

Nevertheless, in the course of their analysis of the topic, several scholars have reached the conclusion that certain characteristics of arbitration in general, or investment arbitration more particularly, are diametrically opposed to independence and impartiality. These irreconcilable conflicts, they argue, require a comprehensive reform of the (ICSID) arbitration system, instead of a piecemeal approach. Several grounds for challenges would thereby be eliminated all at once.

933 Fry and Stampalija, supra note 31, at 190; Reinisch and Knahr, supra note 24, at 103-104; Slaoui, supra note 85 , at 103. But see Kinnear and Nitschke, supra note 13, at 35 (demonstrating that the increasing number of challenges "is broadly consistent with the general trend of increasing cases, although it does not correlate exactly with the number of cases filed in any given year."); Schreuer, Dynamic Evolution, supra note 5, at 19 ("The last ten years have seen a dramatic increase in activity").

934 Levine, supra note 45, at 2.

935 Giorgetti, Challenges, supra note 32, at 303; Markert, supra note 21, at 239.

936 Van Harten, Investment Treaty Arbitration, supra note 7, at 167-174.

937 PAulsson, The IdEA, supra note 22, at 155, 156 and 159 ("The practice of unilateral appointments of co-arbitrators ... is fundamentally at odds with the very concept of arbitration."). 
Paulsson, for example, argues that party-appointments inherently contradict the obligation to be independent and impartial, and therefore proposes that party-appointments should be abolished, or at least restricted to closed arbitrator panels. Horvath and Berzero, as well as Bernasconi-Osterwalder et al. hold ICSID arbitrators' dual functions (as arbitrators and counsel) to be incompatible with their obligation of independence and impartiality. Thus, they propose a prohibition of such dual functions, in order to eliminate an entire range of potential conflicts. The consolidation of the pool of arbitrators which such a prohibition would entail, however, raises questions of diversity and the perceived impenetrability of the community of investment arbitrators, ${ }^{938}$ which are closely related to the issue of independence and impartiality.

These reform proposals will be analyzed in detail in this Chapter. While there are clearly tensions between independence and impartiality on the one hand, and other characteristics or objectives of investment arbitration on the other hand, this Chapter concludes that there is no irreconcilable contradiction, and that the suggested comprehensive reforms would therefore be unwarranted and unsuitable to resolve existing deficiencies of the system.

Based on the finding that the indeterminacy of the challenge threshold is the main flaw of the regulation of independence and impartiality in the ICSID system, the third Part of this Chapter argues that existing concerns would effectively be reduced by clarifying the challenge threshold, and by bringing it into line with the threshold applied in the vast majority of the dispute settlement mechanisms examined in Chapter $3 .{ }^{939}$ Objections regarding the inadequacy of a lower threshold for arbitrator challenges - in light of the small size of the investment arbitration community and of alleged negative repercussions on arbitrators' expertise - are addressed and rejected.

In the fourth Part of this Chapter, the European Union's initiative for an Investment Court System as the most tangible reform proposal (which incorporates the doctrinal proposals discussed in Parts 1 and 2) is outlined and scrutinized.

938 See Puig, Social Capital, supra note 36, at 411; Rivkin, supra note 18, at 356.

939 See also Sheppard, supra note 32, at 155; Giorgetti, Challenges, supra note 32, at 318; PAULSSON, The IdEA, supra note 22, at 16o; DAELE, supra note 51, ๆ ๆ 5-035 and 5-106; Sobota, supra note 27, at 293 and 317. Contra LutTRELL, supra note 31, at 245-246; Markert, supra note 21 , at 273 and 275 (suggesting, however, that in certain exceptional cases, the arbitrator should resign). 
Disputing parties do not chose the arbitrators they appoint merely on the basis of their experience and skills. While such factors certainly matter, what is pivotal for the parties is whether a particular nominee will enhance their chances of winning a case. ${ }^{940}$ This fact was openly acknowledged by the unchallenged arbitrators in the ICSID challenge decision in OPIC:

The suggestion ... that multiple appointments are likely to be explicable on the basis of a party's perception of the independence and competence of the oft appointed arbitrator is in our view unpersuasive. In a dispute resolution environment, a party's choice of arbitrator involves a forensic decision that is clearly related to a judgment by the appointing party and its counsel of its prospects of success in the dispute. In our view, multiple appointments of an arbitrator are an objective indication of the view of parties and their counsel that the outcome of the dispute is more likely to be successful with the multiple appointee as a member of the tribunal than would otherwise be the case. ${ }^{941}$

Disputing parties and their counsel thus vet arbitrators, and seek them out on account of their previous appointments, the awards rendered by tribunals on which they have served, their positions on particular legal questions and general political and ideological views. ${ }^{942}$ In contrast to commercial arbitration, the relative transparency of the investment arbitration system simplifies this vetting process: Previous appointments of the arbitrator and the outcome of the respective proceedings are relatively easily procurable, making it less necessary to rely on informal information networks among arbitration practitioners. ${ }^{943}$

940 Paulsson, The IdeA, supra note 22, at 155; Hans Smit, The Pernicious Institution of the Party-Appointed Arbitrator, Columbia Fd Perspectives No. 33 (2010), http://ccsi. columbia.edu/files/2014/o1/FDI_33.pdf [hereinafter Smit, Pernicious Institution]; DAE LE, supra note 51, \ 7-002 ("It is common knowledge that parties select their arbitrator to maximize their chances of prevailing."); Doak Bishop \& Lucy Reed, Practical Guidelines for Interviewing, Selecting and Challenging Party-Appointed Arbitrators in International Commercial Arbitration, 14 AR B. INT'L. 395, 395 (1998).

941 OPIC, 947.

942 See DAELE, supra note 51, I 7-002; Paulsson, Moral Hazard, supra note 477, at 352; Shany, supra note 106, at 482-483; Rogers, Ethics, supra note 98, ๆๆ 8.85-8.88 (describing the vetting process in detail); Brower and Rosenberg, supra note 122, at 17 .

943 See Magdalene D'Silva, Dealing in Power: Gatekeepers in Arbitrator Appointment in International Commercial Arbitration, 5 J. InT'L. Disp. Settlement 6o5, 633 (2014). Due to 
This strategic alignment of the appointing party's interests and the nominee's preexisting views, viewed in isolation, is not problematic from the point of view of independence and impartiality, as long as the arbitrator appears to be able to objectively and rationally analyze the case and apply the law to it. ${ }^{944}$ After all, no one who would seriously be considered as a possible arbitrator is a blank slate. While parties are required to appoint arbitrators who are independent and impartial, they are not restricted to inexperienced or ignorant arbitrators. ${ }^{945}$ Independence and impartiality guarantee a fair proceeding, and not a random or unpredictable outcome.

In practice, however, arbitrators have a personal incentive to satisfy their appointing parties' expectations: They are competing for (re)appointments. As a result, anecdotal evidence ${ }^{946}$ suggests, arbitrators tend to favor their

the confidentiality of the tribunal deliberations (ICSID Arbitration Rule 15, para. 1), the outcome of a proceeding cannot directly be ascribed to the views of any particular arbitrator. Accordingly, informal information networks are not entirely dispensable, and choosing an arbitrator on the basis of her or his previous appointments includes a certain degree of guesswork, unless the arbitrator has expressed his personal view on certain issues in a dissenting opinion.

944 Bishop and Reed, supra note 940, at 396; SChreuer et AL., Commentary, supra note 16, Art. 40, I 24; Brower and Rosenberg, supra note 122, at 17 ("[T]here is a critical difference between, on the one hand, Paulsson's feared 'advocate-arbitrator' who 'will help me win the case', and, on the other hand, an arbitrator who is appointed by a party because that party perceives, based on the arbitrator's judicial and/or professional track record, that the arbitrator might be more likely than not to share the party's view of the case. While the former is clearly improper, the latter is benign and in fact commonly practiced.").

945 See Douglas Thomson, "An open mind, not a blank mind": Hanotiau survives challenge by Kazakhstan, Global Arbitration Review (Nov. 26, 2015), http://globalarbitrationreview .com/news/article/34376/an-open-mind-not-blank-mind-hanotiau-survives-challenge -kazakhstan/ ("Parties are entitled to have their claims adjudicated by persons with an open mind, not a blank mind unencumbered by prior experience and learning. To disqualify arbitrators for having previously considered points of treaty arbitration would 'put a premium on ignorance."').

946 The actual bias of investment arbitrators has been studied from an empirical perspective by Susan D. Franck (The ICsID Effect? Considering Potential Variations in Arbitration Awards, 51 Virginia J. 977 (2011); International Investment Arbitration: Winning, Losing and Why, Columbia FDI Perspectives No. 7 (2009), http:// ccsi.columbia.edu/files/2014/o1/FDI_7.pdf; Development and Outcomes, supra note 33; Empirically Evaluating Claims, supra note 33), Daphna Kapeliuk (Collegial Games, supra note 33; Repeat Appointment, supra note 33), Albert Jan van den Berg (Dissenting Opinions, supra note 34), and Gus Van Harten (Arbitrator Behaviour, supra note 35). However, inherent methodological limitations of empirical research render reliable proof of bias 
appointing party, sometimes to a point where they take on the role of representatives, and the chairperson remains the only independent and impartial decision-maker on the tribunal.

In a best case scenario, partisan co-arbitrators cancel each other out, or defend their appointing parties' interests with such fervor that a strong chairperson will ignore them, and draft an award without paying attention to their tactics. ${ }^{947}$ But even such a seemingly unscathed outcome is unsatisfactory: If the parties had wanted their dispute to be resolved by a sole arbitrator, they would have agreed so. ${ }^{948}$ If they have not derogated from the default rule of a tribunal composed of three arbitrators, the assumption must be that they intended for three independent and impartial decision-makers to contribute their knowledge, deliberate on the decision, and share the responsibility for a fair outcome of the proceeding. ${ }^{949} \mathrm{By}$ transferring decision-making authority to three arbitrators, the parties did not acquiesce to the impartiality of only one of them. ${ }^{950}$ More importantly, even if the parties did consent to partial coarbitrators, it would not matter: Independence and impartiality are pivotal to the legitimacy of the individual decision, and the institution as a whole, ${ }^{951}$ and as such are not subject to party autonomy. 952

Furthermore, the reciprocal neutralization of partial party-appointed arbitrators appears to be a theoretical construct which is rather unlikely to occur in practice. It is more probable that if partiality were tolerated, this would trigger drastic positions in party-appointed arbitrators, leaving the chairperson as

impossible. See Rogers, Politics, supra note 17, at 228 and 233; see also Franck, StrucTURE, supra note 41 , at 254.

947 Franck, The Role of International Arbitrators, supra note 24, at 12; Mourre, supra note 113.

948 See ICSID Convention art. 37, para. 2.

949 Schreuer et Al., Commentary, supra note 16, Art. 39, ๆ 92 and 7 (corroborating that the restrictions on national arbitrators imposed by the ICSID Convention seek to avoid a situation in which the chairperson of the tribunal is the only neutral arbitrator, akin to a sole arbirator, who has no choice but to side with one of the partisan arbitrators to achieve a majority).

950 Paulsson, The IdeA, supra note 22, at 17 (conceding that such an agreement at least did not exist ex ante, for as the proceedings evolve, parties might lose sight of the goal of resolving a dispute, and mostly care about winning).

951 Paulsson, The Idea, supra note 22, at 147.

952 ICSID Convention art. 40, para. 2 in connection with art. 14, para. 1. See DAE LE, supra note $5^{1}$, ๆ 5-111 ("The right to appoint an arbitrator ... is ... qualified by the requirement that ... each of the arbitrators shall be independent and impartial."); SCHREUER ET AL., СoMMENTARY, supra note 16, Art. 37, I 2 (listing the requirement of arbitral independence and impartiality pursuant to ICSID Convention art. 40 para. 2 as a limit to the parties' freedom of choice in the constitution of tribunals). 
the only remaining independent and impartial decision-maker on the tribunal with no other option than to pick a side, in order to achieve a majority. ${ }^{953}$ Clearly, this would undermine the system's procedural fairness, and thus its legitimacy.

Several scholars, most notably Jan Paulsson, therefore advocate the abolishment of party-appointments. ${ }^{954}$ Criticizing that party-appointments risk skewing the deliberations process by introducing an adversarial element into it, ${ }^{955}$ he concludes that they are "incompatible with the very concept of impartial dispute resolution. ${ }^{956}$ Others more cautiously point out the inherent tension between the concepts of independence and impartiality on the one hand, and the desire for an ally on the tribunal on the other hand..$^{957}$

The abolishment of unrestricted party-appointments, ${ }^{958}$ however, is not the only possible way of dealing with arbitrator bias. Alternative appointment methods would therefore have to entail a higher degree of independence and impartiality, without compromising the valid interests served by party-appointments, in order to be supportable. Two possible alternatives will be examined hereinafter, ${ }^{959}$ with regard to the extent to which they would

953 In the context of the drafting process of ICSID Convention art. 39, see SCHREUER ET AL., Commentary, supra note 16, Art. 39, ๆ 2 and 7.

954 Paulsson, Moral Hazard, supra note 477, at 348 and 352. See also Smit, Pernicious Institution, supra note 940 (advocating a ban on party-appointed arbitrators, unless their role as advocates for the party that appointed them is fully disclosed and accepted).

955 Paulsson, The IdeA, supra note 22, at 156-157.

956 Id. at 162.

957 Park, Arbitration's Discontents, supra note 24, at 594; Shany, supra note 106, at 473 and 488; DAELE, supra note 51 , at 238-239 n.66.

$95^{8}$ Paulsson suggests that party-appointments should either be abolished altogether, or modified, by requiring appointments from a roster. Both suggestions are herein referred to as abolishing unrestricted party-appointments, for the sake of brevity. It is not thereby suggested that under the current ICSID regime, party-appointments are entirely unrestricted.

959 The suggestion of joint appointments by the parties (Paulsson, Moral Hazard, supra note 477 , at 352) will not be analyzed, because the experience with the appointment of wTO panelists demonstrates the ineffectiveness of such an appointment mechanism: The disputing parties rarely reach an agreement on the panelists, leaving the appointment to the Director-General in most instances. See VAN DEN Bossche AND Zdouc, supra note 517, at 216; Spak and Kendler, supra note 517, at 167. In commercial and investment arbitration, the joint appointment of the chairperson by the parties (or their counsel) is often a protracted process, despite the unilateral appointment of the co-arbitrators. Accordingly, it appears unrealistic to expect the parties to agree on all arbitrators, within a reasonable delay. The constitution of a permanent panel of arbitrators, or of an investment court, 
increase arbitrators' independence and impartiality, as well as parties' confidence in the process, while guaranteeing the high quality of arbitrators and awards. 960

\subsection{Appointment by a Neutral Body}

One of the alternatives to party-appointments proposed by Paulsson is to interpose an institution into the appointment process, so that arbitrators would no longer be directly connected to the parties. ${ }^{961}$ The institution which first comes to mind in this context, because it is already in charge of appointing arbitrators who have not been appointed by the parties, as well as members of ad hoc Committees in annulment proceedings, is the ICSID Secretariat, in particular the ICSID Secretary-General. ${ }^{962}$ There are however several objections to having the Secretary-General appoint all three arbitrators:

First, the power monopoly of the Secretary-General is already criticized today, and referred to as a "monarchy, and an absolute rather than a constitutional one." ${ }^{\prime 93}$ At the core of this criticism lies the perception that the appointment of all ad hoc Committees by only one person concentrates too much power in one hand. While it is unclear whether it is indeed only the Secretary-General who makes those appointments, or whether the President of the World Bank, the parties and the Secretary-General cooperate, ${ }^{964}$ there seems to be widespread agreement that the criteria applied to such appointments lack transparency: Although appointments should be made from the Panel of Arbitrators, ${ }^{965}$ this requirement is often foregone, and waived by the disputing parties, or their counsel. Accordingly, the process is said to be highly discretionary and random. Due to the lack of oversight (except for the

is not examined because this study focuses on improving arbitrator independence and impartiality within the current institutional system, i.e. in an arbitration setting.

96o See also Mourre, supra note 113 .

961 Paulsson, Moral Hazard, supra note 477, at 352. See also Smit, Pernicious Institution, supra note 940.

962 Under ICsID Convention art. 38 and art. 52, para. 3, this is the competence of the ICSID Chairman (i.e. the President of the World Bank). In practice, however, it is often delegated to the Secretary-General, who is more familiar with the potential nominees. See Douglas Thomson, Is ICSID a "Monarchy"?, Global Arbitration Review (Jan. 4, 2016), http:// globalarbitrationreview.com/news/article/34415/is-icsid-monarchy/ [hereinafter Thomson, Monarchy].

963 Id.

964 Id. (statement by Antonio Parra, a former senior counsel, legal adviser and deputy secretary general at ICSID).

965 ICsid Convention art. 40, para. 1. 
possibility of challenging the appointed arbitrators or ad hoc Committee members), some authors refer to the role of the Chairman as an autocratic one. ${ }^{966}$ As a result, it is unlikely that the appointment of arbitrators by the SecretaryGeneral would elicit more confidence in the dispute resolution process from the parties.

Second, the transfer of the appointment authority from the parties to the Secretary-General would not solve existing independence and impartiality issues, but would transform them into doubts regarding the arbitrators' political neutrality and institutional independence. Prominent arbitration practitioners and scholars have criticized the ICSID Secretariat for what they perceive to be politically motivated interventions in the annulment context, ${ }^{967}$ and a poor selection of ad hoc Committee members. ${ }^{968}$ Others have voiced their distrust towards the President of the World Bank, because he allegedly reflects the dominance of the United States in the decision-making process of the World Bank. ${ }^{969}$ Appointments by the Secretariat or the President might therefore be perceived to be political. In contrast to party-appointments, the potential influence on the decision-makers would be monopolized in the hands of one appointing body, whether it would be the Secretary-General or the ICSID Chairman. With no one to offset and neutralize the appointing body's power, arbitrators would be exposed to accusations of deciding in a way that pleases the institutional appointing body, in order to be reappointed. ${ }^{970}$ The resulting appearance of institutional dependence would be at least as pernicious as bias towards one of the parties.

966 David Collins, ICSID Annulment Committee Appointments: Too Much Discretion for the Chairman?, 30 J. INT'L. ARB. 333, 338 (2013); Mourre, supra note 113.

967 See Vivendi, Decision on the Argentine Republic's Request for Annulment of the Award rendered on Aug. 20, 2007, Separate Opinion of Professor Jan Hendrik Dalhuisen (Aug. 10, 2010), ๆ 2 , 9 (pointing out the Secretariat's interference with and substantive involvement in annulment proceedings, which in his view presumably aims to ensure a restrictive interpretation of the provisions on annulment, in order for a majority of awards to be upheld).

968 Mourre, supra note 113; Paulsson, Moral Hazard, supra note 477, at 354 ("arbitral institutions ... are ... exposed to suspicions of poor selection of arbitrators, and maybe even worse: cronyism and other forms of corruption."); Brower and Rosenberg, supra note 122, at 24 .

969 Collins, supra note 966 , at 338 .

970 Vivendi, Decision on the Argentine Republic's Request for Annulment of the Award rendered on Aug. 20, 2007, Separate Opinion of Professor Jan Hendrik Dalhuisen (Aug. 10, 2010), ๆ 922 and 25 . 
Third, due to arbitrator information asymmetries ${ }^{971}$ and the consolidation of the arbitration community over the past decades, it is unlikely that the Secretary-General or the ICSID Chairman would appoint other arbitrators than the current frequent players. Accordingly, the transfer of the appointment authority to ICSID would have an "acratic effect," as defined by D'Silva:972 Beyond the comforting appearance of a resolution of the independence and impartiality issue, no real change would be achieved in practice. Currently, appointments by the Secretary-General only fare marginally better than partyappointments in terms of diversity, ${ }^{973}$ and potential conflicts of interest arising from repeat appointments are apparently not sufficiently paid attention to by the Secretariat. ${ }^{974}$ Also for this reason, it is doubtful that arbitration users would have confidence in the selection of the decision-makers by the Secretary-General or the ICSID Chairman, ${ }^{975}$ and that existing independence and impartiality issues would be resolved.

Last but not least, the institution appears to already be reaching its capacity limits with the appointments it is now making. As a response to criticism regarding the delegation of the appointment competency from the ICSID Chairman to the Secretary-General, it has been argued that the "sheer number of appointments" handled by ICSID make such an arrangement indispensable. ${ }^{976}$ It is worth highlighting that just over a quarter of all appointments (including

971 Rogers, ETHICS, supra note 98, ๆ $8.84-8.93$.

972 D'Silva, supra note 943, at 610 and 613.

973 ICsid, Caseload-Statistics 2016-1, supra note 3, at 19 and 31.

974 Thomson, Monarchy, supra note 962 (illustrating this allegation with the appointment of Albert Jan van den Berg as a chair of an ad hoc Committee, despite the fact that he had authored an award which one of the parties relied upon in the proceeding, and which had been annulled just three weeks earlier). See also Reed, Paulsson, And Blackaby, supra note 13, at 173-174 ("In recent years, ICSID has made serial appointments to ad hoc committees from a small pool of highly experienced arbitrators, ... 'to promote coherence in the application of the Convention and Rules by annulment committees'. As a result, the 20 ad hoc committees constituted by ICSID between January 2007 and September 2010 have been made up primarily of arbitrators serving on multiple committees. Out of a total of $6 \mathrm{o} \mathrm{ad} \mathrm{hoc} \mathrm{committee} \mathrm{member} \mathrm{positions,} 15$ arbitrators have held over three-quarters of the appointments (49 out of 60 positions, or 81 percent).").

975 Paulsson, Moral Hazard, supra note 477, at 354; Brower and Rosenberg, supra note 122, at 24 ("[I]t is highly to be doubted that any institution can ever achieve a level of user confidence that even approaches that of selections made by sophisticated parties and counsel.").

976 Thomson, Monarchy, supra note 962 (comment by Eloise Obadia, a former senior counsel at ICSID). 
appointments to ad hoc Committees) are currently made by the institution ${ }^{977}$ if this workload brings ICSID to its limits, it is unlikely that it could manage the appointment of all arbitrators.

In summary, the appointment of arbitrators by the Secretary-General or the ICSID Chairman would neither increase arbitrators' independence and impartiality, nor parties' confidence in the process. Due to the lack of knowledge of the particular needs of the disputing parties with regard to the arbitrator's expertise, the appropriate specialization of the appointed decision-makers could not be guaranteed, either. ${ }^{978}$ On balance, this alternative is not considered an avenue worth pursuing.

Another possibility for interposing an institution into the appointment process would be to charge the ICSID Administrative Council ${ }^{979}$ or a committee established within the Administrative Council with arbitrator appointments. This has been suggested by Collins, in the context of the appointment of ad hoc Committees, and is inspired by the appointment procedure for the WTO Appellate Body. 980

Undoubtedly, this solution would be more transparent, participatory and democratic than having the Secretary-General or the ICSID Chairman appoint the arbitrators. It is however doubtful that the Administrative Council could deal with the number of appointments that would need to be made. The appointment of the WTо Appellate Body members is limited to seven nominations within four years. ICSID, on the other hand, has registered between thirty-eight and fifty-two cases a year over the past five years. ${ }^{981}$ In addition, annulment proceedings were commenced in thirty-one cases since 2011 more than a third of the eighty-two awards which were rendered. ${ }^{982}$ Assuming that the same body would appoint arbitrators and ad hoc Committee members, it would have to make more than one hundred and fifty appointments

\footnotetext{
977 ICSID, Caseload-Statistics 2016-1, supra note 3, at 19 and 31.

978 Brower and Rosenberg, supra note 122, at 19 ("Naturally, the parties and their counsel know more about the specific nuances of their case than anyone else, including an Appointing Authority. The parties likewise are in the best position to identify the corresponding knowledge, skills, and expertise desired (or needed) in a tribunal to adjudicate the dispute.").

979 ICSID Convention art. 4-8. The ICSID Administrative Council is the governing body of ICSID. It is composed of one representative from every contracting State.

980 Collins, supra note 966, at 340.

981 ICSID, Caseload-Statistics 2016-1, supra note 3, at 7.

982 International Centre for Settlement of Investment Disputes, The ICsID Caseload-Statistics (Issue 2015-2), at 17, https://icsid.worldbank.org/apps/ICSIDWEB/resources/Documents/ ICSID\%20Web\%2oStats\%202015-2\%20(English).pdf.
} 
a year, overall. This is a considerable workload. Finding consensus on such a large number of appointments, and on potential replacements, without compromising the suitability and qualifications of the arbitrators, is likely to be difficult.

The suggestion of transferring the appointment authority to a committee within the Administrative Council appears to be more practicable, but harbors a considerable risk of either a politicization of the process, ${ }^{983}$ or of no effect on the outcome of appointments: Like the Secretary-General, a committee within the Administrative Council would lack the necessary insight to identify arbitrators who are particularly suited to decide a specific dispute. ${ }^{984}$ In contrast to arbitration practitioners, it is also unlikely to be aware of qualified and motivated newcomers who could serve as arbitrators. ${ }^{985}$ As a consequence, such a committee would largely rely on seasoned ICSID arbitrators in its nominations, just like the Secretary-General or the ICSID Chairman.

Consequently, also this alternative (should it be practicable) would not effectively improve arbitrators' independence and impartiality, without impairing parties' confidence in the process.

\subsection{Party-appointment from a Roster}

The second alternative to prima facie unrestricted party-appointments would be to limit appointments by the parties to an exhaustive roster of qualified arbitrators. ${ }^{986}$

To date, attempts to create such rosters have been unsuccessful in several dispute resolution mechanisms: In the ICSID system, many States fail to nominate arbitrators to the Panel of Arbitrators provided for in Article 12 ICSID Convention. ${ }^{987}$ The roster of arbitrators of the PCA was originally intended to be closed, but is mostly insignificant today, and parties can freely appoint anyone

\footnotetext{
983 See infra Part 1.2.

984 Brower and Rosenberg, supra note 122, at 19.

985 Id. at 24.

986 Paulsson, Moral Hazard, supra note 477, at 352; Wouters and Hachez, supra note 19, at 637.

987 The Panel of Arbitrators binds the ICSID Chairman in his appointment of arbitrators and ad hoc Committee members. Under ICSID Convention art. 13, each Contracting State may designate four persons to the Panel of Arbitrators. In addition, the ICsID Chairman may designate ten persons. If every Contracting State made use of this right, there would accordingly be 618 arbitrators on the panel (including those appointed by the ICSID Chairman). To date, there are however only 243 arbitrators on the panel. See Database of Panel Members - Panel of Arbitrators, International Centre for Settlement of InVEStment Disputes, https://icsid.worldbank.org/apps/ICSIDWEB/about/Pages/ Database-of-Panel-Members.bak.aspx (last accessed on Mar. 7, 2016).
} 
as an arbitrator. ${ }^{988}$ A roster for NAFTA investment disputes (the equivalent of the ICSID Panel of Arbitrators) still has not been created, ${ }^{989}$ just like the list of substitute third-country Members for the Iran-United States Claims Tribunal. ${ }^{990}$ But even if the member States of the ICSID Convention succeeded in creating a roster of arbitrators, ${ }^{991}$ such a roster would be problematic in several ways:

First, there appears to be no appropriate size of a roster which would reduce the risk of dependence and partiality without unnecessarily curtailing the diversity and the expertise of the decision-making body. From the perspective of arbitrators' independence, a large roster would be ineffective. Its members would not be assured of receiving appointments, and would therefore continue to compete for nominations. They might, of course, enter the competition for appointments by offering particular qualifications, experience in a specific area of expertise, or a high degree of impartiality. The parties' focus on winning, however, would likely lead to the appointment of arbitrators who discreetly but unmistakably signal their political and ideological preferences, and defend their appointing parties' positions on the tribunal. There is no objective reason why arbitrators who are part of a large roster would be less tempted to attract (re)appointments by favoring their party than arbitrators in the current system. ${ }^{992}$ The panel would therefore have to be small. It would have to be so small that the competition for appointments among arbitrators would be largely eliminated. Being included on the roster would virtually have to guarantee an arbitrator that she or he will get appointed to tribunals. Such a short roster would however not only de facto eliminate the parties' freedom of choice; it would also increase the chances of repeat appointments and of the arbitrators' familiarity with counsel and with the subject-matter of a case. ${ }^{993}$ The most frequently invoked bases for arbitrator challenges therefore would not be eliminated, and favoritism could still occur. ${ }^{994}$ At the same

988 Daly, Goriatcheva, and Meighen, supra note 637, 9 4.38.

989 Brower and Rosenberg, supra note 122, at 12.

990 Iran-United States Claims Tribunal Rules of Procedure, 2 Iran-U.s. Cl. Trib. Rep. 403, art. 13 note (1983). See also Brower and Rosenberg, supra note 122, at 12.

991 The current Panel of Arbitrators (ICSID Convention art. 12) serves a more limited purpose than if all arbitrators were appointed from it. Accordingly, it would have to be renewed, and (probably) enlarged if it were to list all available candidates for arbitrator and ad hoc panels.

992 See also Santens, Move Away, supra note 127.

993 Id.

994 A short roster might even aggravate arbitrators' bias. In the context of the Court of Arbitration for Sport (CAS), for example, a stricter standard of independence and impartiality 
time, diversity and expertise on such a small roster would be significantly curtailed.

Second, as argued above, in the context of the suggestion for an institutional appointment of arbitrators, it is questionable whether a closed roster of arbitrators would list other arbitrators than those who currently dominate the investment arbitration scene. This is not to say that it would be desirable not to list the current arbitrators on the roster. On the contrary, the system is dependent on these specialists, who have the necessary expertise and experience. These arbitrators, however, would not suddenly wipe the slate clean and abdicate their political and legal views, their past decisions, or their positions and functions within the investment arbitration network, only because they are listed on a roster. If parties appoint them based on these criteria today, they would continue to do so. Accordingly, a roster would not bring about as much change as one might expect. At the same time, limiting the number of potential decision-makers would take a toll on diversity and expertise ${ }^{995}$ especially if the roster was kept short, in the interest of independence. It would also constitute an additional hurdle to new entrants. ${ }^{996}$ These drawbacks are too significant, in the light of the minor improvement (if any) which could be achieved in the independence and impartiality context.

Third, a roster would inevitably lead to a politicization of ICSID arbitration. Whether the member States would nominate the members of the Panel of Arbitrators, as is the case in current international adjudication and sui generis mechanisms which provide for rosters, ${ }^{997}$ or whether the ICSID Chairman would participate in the nomination process, ${ }^{998}$ potential arbitrators would have difficulties getting listed if they did not entertain close connections with the contracting States or the ICSID Secretariat. ${ }^{999}$ Appointments which would go beyond the current pool of investment arbitrators are likely to be guided

has been advocated - precisely because the roster is closed and relatively short, and therefore increases the likelihood of repeat appointments. See Antonio Rigozzi, Challenging Awards of the Court of Arbitration for Sport, 1 J. InT'L. DisP. SettLement 217, 239 (2010).

995 Brower and Rosenberg, supra note 122, at 24.

996 Id. at 23; Santens, Move Away, supra note 127.

997 DSU art. 8, para. 4 ("Members may periodically suggest names of governmental and nongovernmental individuals for inclusion on the indicative list."); 1899 The Hague Convention art. 24; 1907 The Hague Convention art. 45.

998 ICSID Convention art. 13, para. 2.

999 Brower and Rosenberg, supra note 122, at 23 ("Politics ... create an artificial barrier to entry, which conflicts with, for example, the '[n]eed for additional qualified arbitrators on the ICSID Panels due to the increasing caseload', as recently emphasized by the ICSID Secretary-General."). 
by the appointees' general political and ideological views. Such nominations often entail extensive lobbying campaigns and subsequent allegiances, ${ }^{1000}$ which are no less problematic than dependence on or partiality towards one of the parties. ${ }^{1001}$ Furthermore, the periodic renewal of the roster and possibility of a re-election of its members would pose similar problems as tenure and reelection in international adjudication, and would most likely result in similar national and geopolitical biases. ${ }^{1002}$

As a consequence, any potential gains a closed roster might have are likely to be offset by the problems it would create. In summary, the party-appointment of arbitrators - paired with clear rules on arbitrators' independence and impartiality, and the enforcement of these rules in an objective and effective process - is preferable to any of the alternative suggestions. ${ }^{1003}$

\section{$2 \quad$ Prohibition of Dual Functions}

The non-exclusive nature of the arbitrator function is frequently at the core of disqualification requests. In particular, the primary (or coequal) activity of arbitrators as legal advisors and counsel can cause an apprehension of bias under certain circumstances. For example, when one of the parties in the arbitration has an attorney-client relationship with the arbitrator, sympathies or the identification with this party's general position might influence the arbitrator's decision. If the arbitrator is faced with a legal question which she has previously argued as a counsel, she might not approach it as open-mindedly as if it was new to her. If the arbitrator is involved (as a counsel) in a parallel proceeding concerning similar legal issues, the awareness that his award might support or impede his arguments as a counsel might influence his decision-making.

1000 Id. at 22-24. See, in the context of ICJ ad hoc judges, Kooijmans, supra note 128, 17 (stating that ad hoc judges predominantly cast their votes in favor of their appointing State); Mackenzie and Sands, supra note 510 , at 278.

1001 Santens, Move Away, supra note 127.

1002 See Erik Voeten, The Impartiality of International Judges: Evidence from the European Court of Human Rights, 102 Am. Polit. SCI. Rev. 417, 421 (2008); Erik Voeten, International Judicial Independence, in Interdisciplinary Perspectives on International LaW and International Relations. The State of the Art 421, 431-434 (Jeffrey L. Dunoff \& Mark A. Pollack eds., 2012); Posner AND De Figueiredo, supra note 516, at 28-29; Mackenzie and Sands, supra note 510, at 278. But see Smith, supra note 120, at 200.

1003 Chiara Giorgetti, Who Decides Who Decides in International Investment Arbitration?, 35 U. PA. J. INT'L. L. 431, 473-474 (2013). 
Based on the multitude of (conscious or unconscious) conflicts of interest which such dual functions can entail, various scholars suggest that they should be prohibited altogether. Arbitration professionals should be faced with the choice of either practicing an adjudicatory or a counsel role, and should not be allowed to switch between the two. ${ }^{1004}$ The merits of three different versions of such a ban are examined hereinafter.

\subsection{Complete Prohibition}

A complete prohibition of dual functions would undoubtedly prevent various situations of potential conflict from arising in the first place. Role switching between counsel and arbitrators, for example, would be completely forestalled. Situations in which arbitrators could adjudicate disputes involving their current clients would be avoided. Potential conflicts based on an arbitrator's previous collaboration with one of the counsel in the proceeding would eventually become less frequent. Procedurally, a complete prohibition would simplify conflict checks and disclosures. Fewer dilatory challenges based on the interests arbitrators have in their role as counsel would mean less delays in the resolution of disputes. Completely banning dual functions, however, would also be a very drastic and far-reaching measure - one whose disadvantages would outweigh any potential benefits.

First, banning arbitrators from working as counsel would be over-inclusive, and therefore disproportionate. A complete ban of dual functions would also cover situations in which the two functions do not interfere with each other, and where no danger of a conflict of interest exists. ${ }^{1005}$ In these situations, the ban would eliminate the positive implications of dual roles, ${ }^{1006}$ without improving arbitrators' independence and impartiality. Because arbitrator and counsel functions do not always conflict, the rare cases in which they do can better be managed with clear and targeted rules on conflicts of interest, which would require the recusal, or (ultima ratio) the removal of an arbitrator in such a situation. The clarification of conflict of interest rules would accomplish more legal security and predictability across the board than an outright ban of

1004 Mouawad, supra note 252, at 12; Bernasconi-Osterwalder, Johnson, and Marshall, supra note 32 , at 51 ; Horvath and Berzero, supra note 37 , at 18.

1005 Arbitrators who consistently ensure that their appointments are not connected to their work as counsel (i.e. neither to a client, nor to a specific legal issue they have previously dealt with), for example, would also be affected by the ban. Not an open, but a blank mind of arbitrators would be ensured by such an over-inclusive ban on dual functions.

1006 The availability of experienced professionals, who know all aspects of investment arbitration proceedings, from all perspectives, for example, is said to be an advantage of the dual function of arbitrators. Horvath and Berzero, supra note 37, at 12. 
dual functions, which only aims at a small subset of potential conflicts, and is over-inclusive.

Second, a complete prohibition of dual functions would be ineffective, if not counterproductive. By eliminating arbitrators' main and most reliable source of income ${ }^{1007}$ - counsel fees - arbitrators would be made more, instead of less dependent on party (re)appointments. ${ }^{1008}$ It is realistic to assume that a prohibition of dual functions would significantly reduce the number of available arbitrators, since counsel work is both more reliable, and more lucrative than arbitrator appointments. ${ }^{1009}$ The pool of investment arbitrators, which is already small as it is, would thus become even more concentrated. ${ }^{1010}$ Seasoned arbitrators would likely be the only ones for whom it would be economically viable to pursue a career which is exclusively focused on the arbitrator function. It is imaginable that they would decide a vast majority of all investment disputes if dual functions were prohibited, probably in relatively constant roles (appointed by a particular category of parties, or serving as the chairperson) on different tribunals. Such a consolidation of the investment arbitrator community would entail a loss of diversity, and a tightening of the existing network and interdependencies. Repeat appointments by the same parties or counsel, against the same parties, or in similar matters would be virtually unavoidable, and the positions of the remaining arbitrators would likely become more entrenched.

1007 LUtTRELL, supra note 31, at 239; STIPANOWICH AND UlRICH, supra note 105, at 19-23 (providing empirical data on the work time utilization of commercial arbitrators).

1008 See DAELE, supra note 51, ๆ 6-191 ("If the arbitrator has independent income sources, he/ she will be less tempted to vote in favour of the appointing party so as to secure future appointments and future income.").

1009 See ICSID, Schedule of Fees, § 3, https://icsid.worldbank.org/apps/ICSIDWEB/icsiddocs/ Pages/Schedule-of-Fees.aspx (last accessed on Dec. 30, 2016) ("In addition to receiving reimbursement for any direct expenses reasonably incurred, conciliators, arbitrators, commissioners and ad hoc Committee members are entitled to receive a fee of US $\$ 3$,ooo per day of meetings or other work performed in connection with the proceedings, as well as subsistence allowances and reimbursement of travel expenses within limits set forth in Administrative and Financial Regulation. Any request for a higher amount shall be made through the Secretary-General."). See also Reed, Paulsson, And Blackaby, supra note 13, at 16-17 ("These fees remain modest when compared with those typically charged by leading arbitration professionals in their other work."); Puig, Social Capital, supra note 36 , at 398 n.61.

1010 Contra Horvath and Berzero, supra note 37, at 13 (" $[\mathrm{I}] \mathrm{t}$ is not true that prohibiting practitioners to wear double-hats would reduce the available 'pool' of experienced arbitrators. Rather, it can be argued that it would result in the convergence of professors, civil servants, diplomats etc. which would, at the end of the day, enrich the arbitral process."). 
An outright ban of dual functions further only helps to avoid conflicts which arise from an arbitrator's personal and concurrent function as a counsel. This only covers a very small portion of possible conflicts. Arbitrators would presumably remain integrated into law firms, and receive appointments through their law firms' networks. Some of the connections of those law firms, or of their colleagues, would have to be imputed to them, as is already the case today. Such conflicts would not be eliminated by a ban of dual functions. Neither would conflicts arising from an arbitrator's previous work as a counsel. Since most arbitrators serve as counsel to arbitration parties, tribunal secretaries and tribunal assistants, long before they receive their first appointments, it is inevitable that they build their professional network and connections at that time. It might even be realistic to assume that they are most actively building up their network before they even become appointed for a first time, because they are working towards precisely that goal: a first appointment. A prohibition of dual roles would not change this dynamic, despite the acute potential for conflict. It would only hinder the formation of additional connections (in the capacity as counsel), after a lawyer has become an arbitrator. Accordingly, a large proportion of potentially conflicting connections would not be covered.

In summary, a complete ban of dual functions would not solve all independence and impartiality concerns. It would be over-inclusive in some respects, and under-inclusive in others, while the ensuing consolidation of the investment arbitrator community would likely compound existing concerns.

\subsection{Temporary Prohibition and Vesting Period}

An attenuated version of a complete ban would be a temporary incompatibility, paired with a vesting period, as provided for with respect to ICJ ad hoc judges in Practice Directive VII. ${ }^{1011}$ Practice Directive VII obliges ICJ ad hoc judges to avoid serving as counsel in ICJ cases within a three year period of their service as an ad hoc judge. The prohibition is not restricted to the service in cases which are related, or in which the facts, the law or the parties overlap. Instead, it intends to "create a certain distance between the bench and the bar."1012 The simultaneous or recently sequential exercise of the two roles is generally prohibited. Despite this strict rule (which is not binding, but is generally obeyed), the pool of individuals qualified enough to act as ad hoc judges has not become so small as to pose a problem to the functioning

1011 See supra Chapter 3, Part 1.2 A.

1012 Kooijmans, supra note 128, ๆ 19. 
of the ICJ, as had been feared. ${ }^{1013}$ Some scholars have voiced the view that if the ICJ requires a temporary separation of counsel and adjudicator roles, this should also (or all the more) be the case in investment arbitration. ${ }^{1014}$

ICJ ad hoc judges, however, are an anomaly in this context. In all other examined dispute resolution mechanisms, the decision-makers are free from any restrictions with regard to the professional activities they otherwise pursue. None of the examined commercial arbitration rules provide for incompatibilities, nor do the arbitration rules of the PCA. WTO panelists are frequently government trade officials, academics or private trade law practitioners - clearly unrestricted by any rules on incompatibilities. Furthermore, the vesting period provided for in Practice Directive viI is less of a threat to the functioning of the ICJ than it would be in any other examined system, since expertise on the ICJ is ensured by its permanent members. In the ICSID system, such a temporary incompatibility would likely have the same effect as a complete prohibition, with the same drawbacks.

As a result, a temporary prohibition of dual functions also has to be rejected. Dual functions should only be prohibited where they actually conflict, i.e. where issues which are key or outcome-determinative in one of the arbitrator's roles also arise in the other role. ${ }^{1015}$ Such a resolution of potential conflicts on an individual basis, with a view to the specific circumstances of the situation, is more proportionate and more effective.

\subsection{Disinvolvement upon Challenge?}

An interesting question arising in cases where the concurrent counsel role or membership in a law firm raises doubts about the arbitrator's independence or impartiality, is whether the arbitrator's disinvolvement should be considered to resolve any such doubts, and prevent a disqualification. Under the UNCITRAL Arbitration Rules, several arbitrator challenges have resulted in an invitation to the arbitrator to discontinue either of her or his roles to avoid disqualification. ${ }^{1016}$ Similarly, in a number of ICSID arbitration proceedings,

1013 Watts, supra note 489, at 254; Couvreur, Article 17, supra note 488, 1 17. Inferences for the ICSID system should however not be made incautiously, since ICJ and investor-State arbitration proceedings differ in important respects. See Bernasconi-Osterwalder, Johnson, and Marshall, supra note 32 , at 37.

1014 Fiona Marshall, Defining New Institutional Options for Investor-State Dispute Settlement 12 (2009), available at http://www.iisd.org/pdf/20og/defining _new_institutional_options.pdf.

1015 Mouawad, supra note 252, at 12.

1016 See Grand River, Telekom Malaysia, and Vito Gallo. 
arbitrators have left their law firms to (successfully) avoid their removal from the tribunal. ${ }^{1017}$

To consider doubts regarding an arbitrator's independence and impartiality dispersed or evaded because of a purely formal act would however be inconsistent with the importance of appearances and perceptions for disqualification decisions, and overly formalistic. Where an arbitrator has concurrently acted in two incompatible roles, the doubts this creates persist, even if the arbitrator discontinues one of the roles. The reciprocal influence of the conflicting roles cannot be undone by the arbitrator's resignation. This is even more so if the arbitrator has acted as a counsel in the problematic case for a long time, and if stepping down was not her or his own choice, but a reaction to the request of an authority deciding on a disqualification request. Such a disinvolvement is not precautionary, but a mere formality to avoid a disqualification. In the view of a reasonable third person, it is unlikely to change anything about the arbitrator's mind-set.

\section{Clarification of the Threshold for Arbitrator Challenges}

The analysis of past ICSID challenge decisions in Chapter 2 has shown that the interpretation of the manifest lack requirement stipulated in Article 57 ICSID Convention is anything but settled. Its interpretation by arbitrators and by the ICSID Chairman ranges from requiring the objective proof of manifest bias to accepting inferences of a reasonable appearance of partiality or justifiable doubts as to the arbitrator's independence and impartiality. A series of challenge decisions rendered between 2013 and 2015 seemed to be signaling a more consistent application of a justifiable doubts threshold. The most recent disqualification decisions, however, have interrupted this trend. As a consequence, the threshold for arbitrator challenges under Article 57 ICSID Convention is still ambiguous. This opacity is problematic for four main reasons:

First, an indeterminate standard fails to reduce the number of unsuccessful challenges. ${ }^{1018}$ While a clear standard has a gatekeeping function by signaling to the parties what the minimum requirements for a successful disqualification request are, an indeterminate threshold cannot fulfill this function. Accordingly, more challenges than necessary are filed and proceedings are needlessly delayed.

1017 See Azurix, Siemens, the ConocoPhillips challenges, and the Favianca challenges.

1018 Rogers, Ethics, supra note 98, \ 2.67. 
Second, in light of the contradictory interpretations of the threshold for challenges, the participants in an arbitration proceeding (parties, counsel and arbitrators) are never assured that an appointment will withstand their counterparty's challenge. This insecurity is likely to either lead to an overly cautious or to an overly sanguine approach to the choice of arbitrator. Both reactions are undesirable: The cautious party will appoint a less qualified, but undoubtedly impartial arbitrator, while the confident party will appoint a potentially partial arbitrator, instead of looking for a more neutral candidate. A combination of the two approaches inevitably leads to the constitution of a lopsided tribunal. ${ }^{1019}$

Third, the uncertainty of the threshold might prevent parties which have justified objections to an arbitrator's appointment from filing a challenge, based on the unpredictability of the outcome.

And fourth, the contrast between the inconsistency of the applicable challenge threshold on the one hand and the uniformity of the outcome of challenge decisions on the other hand (namely, the dismissal of all but three disqualification requests) could create the impression that challenges are decided without any regard to the relevant standard.

All of these drawbacks of an uncertain challenge threshold would undermine the legitimacy of ICSID arbitration as a superior, fair and rules-based dispute resolution mechanism. Accordingly, a clarification of the relevant threshold is urgently needed.

\subsection{Excessive Rigor of the Strict Proof Threshold}

The strict proof threshold established in Amco Asia and applied in numerous subsequent challenge decisions imposes an excessive burden of proof on the challenging party. As previously stated, independence and impartiality are states of mind which are not open to the scrutiny of the observer. Accordingly, the production of objective proof for an arbitrator's bias is only possible in the most exceptional cases. ${ }^{1020}$ According to Paulsson, it is more likely to be available if an inexperienced arbitrator inadvertently breaches his duty of impartiality. ${ }^{1021}$ On the other hand,

[t]he truly harmful cases remain unknown, because improper behavior is shrouded in urbane subterfuge and hypocrisy. It is extraordinarily difficult to police. ${ }^{1022}$

1019 Id. ๆ 8.81.

1020 See also Tupman, supra note 43, at 49 .

1021 See the example given in Paulsson, The IdEA, supra note 22, at 159.

1022 Id. at 160. 
Since such a heavy burden of proof makes it virtually impossible for parties to achieve the disqualification of an arbitrator, it renders their right to an independent and impartial decision-maker illusory. ${ }^{1023}$ Arbitrators are effectively insulated from any adverse consequences of unethical behavior. As a result, the application of a strict proof threshold to challenges of ICSID arbitrators would further exacerbate the oft-cited perception of the international arbitrator community as a "mafia." 1024 Such a reputation would harm the legitimacy of the system, and must therefore be avoided.

\subsection{Adequacy of the Justifiable Doubts Threshold}

Based on the prevalence of the justifiable doubts standard in most comparable dispute resolution mechanisms, ${ }^{1025}$ various scholars suggest that the same threshold should govern challenges of ICSID arbitrators. ${ }^{1026}$ Others disagree, cautioning that this standard would be inappropriate in the ICSID system. ${ }^{1027}$ Their objections evolve around a common theme: The small size of the investment arbitration community, and the resulting incidence of contacts between its members. They argue that given this particular environment, disqualifications would more frequently occur if a justifiable doubts standard was applied - so much so, that the availability of qualified arbitrators would be limited. ${ }^{1028}$ Furthermore, harmless contacts within the arbitration community - which are argued to be beneficial for the arbitrators' expertise would be impeded, because the threat of a disqualification would forthwith hover over the arbitrators' heads like the sword of Damocles. As a consequence, the prioritization of independence and impartiality (in the form of a lower

1023 Giorgetti, Challenges, supra note 32, at 317; Fry and Stampalija, supra note 31, at 263. DAELE, supra note $5^{1}, \mathbb{9} 5^{-034}$ (highlighting that this is "all the more true in the early stages of the arbitration proceedings, when the parties have not yet been in the position to evaluate the arbitrator's actual behaviour and attitude."); Sobota, supra note 27, at 312 and 316.

1024 Yves Dezalay \& Bryant G. Garth, Dealing in Virtue. International Commercial Arbitration and the Construction of a Transnational Legal Order 50 (1996). See also Rogers, Ethics, supra note 98, ๆ 2.03 .

1025 See supra Chapter 3, Part 5.2. The ICJ Rules and the wTo Rules of Conduct are singular exceptions to the otherwise predominant applicability of the justifiable doubts standard.

1026 Sheppard, supra note 32, at 155; Giorgetti, Challenges, supra note 32, at 318; PAulsson, The IDEA, supra note 22, at 160; DAELE, supra note 51, 9 9 5 $5^{-035}$ and 5-106; Sobota, supra note 27 , at 293 and 317 . The persuasive authority of the relevant standards in other international arbitration systems was acknowledged in Alpha Projektholding (I 33) and Vivendi ( $(24)$.

1027 LUtTRELL, supra note 31, at 245-246; Markert, supra note 21, at 273 and 275 (suggesting, however, that in certain exceptional cases, the arbitrator should resign).

1028 Trakman, supra note 819, at 126; Kee, supra note 22, at 194. 
challenge threshold) would impair the quality of the system, and have a negative impact on arbitrators' expertise.

As far as these objections result in the demand for a strict proof of bias, the previous Part has demonstrated the inadequacy of such a threshold. The argument that the justifiable doubts standard is too strict in view of the small size of the investment arbitration community is incorrect for the following reasons:

The justifiable doubts threshold is an objective standard, which requires the facts on which the challenge is based to raise doubts as to the arbitrator's independence and impartiality in a third person, and not just in the challenging party. Thus, challenges based on innocuous circumstances will be dismissed under the justifiable doubts standard, just like they would be dismissed if a higher threshold was applied. The concept of justifiable doubts is inherently malleable, and adapts to the context of the specific dispute resolution mechanism. ICSID challenge decisions in which a justifiable doubts threshold was applied bear witness to this flexibility: A vast majority of the requests were dismissed, proving that the standard is not too strict, and certainly adequate to thwart unmeritorious challenges. Accordingly, vexatious challenges would be no more successful under the justifiable doubts standard than under any stricter threshold, ${ }^{1029}$ and concerns about a potential chilling effect on beneficial professional contacts within the arbitration community are unfounded.

Far from impairing the quality of ICSID arbitration, as critics claim, a lower threshold for arbitrator challenges could actually contribute to a solution of many issues which the small size of the investment arbitration community entails. A more realistic approach to potential conflicts of interest would disqualify certain arbitrators from adjudicating specific disputes, or from being appointed by a particular party. This would open the door for a more frequent appointment of arbitrators who now only rarely (or never) serve on tribunals, but who have gathered enough experience as counsel in arbitration to take on such a role. It would encourage entirely new appointments of equally qualified arbitration practitioners, scholars or former government officials. This lowering of the entry barriers to the market for arbitrator services would lead to an incremental enlargement of the arbitrator community. In turn, problematic

1029 See also DAELE, supra note $5^{1}$, I $5^{-110}$. Daele convincingly demonstrates that the numbers of challenges are not increasing in other international arbitration systems, in which a reasonable doubts test is applied. He also clarifies that there is no correlation between the applicable threshold and the incidence of dilatory challenges, because "if a party really wants to make a bad faith challenge to frustrate and delay the proceedings, it will simply do so, irrespective of how high or low the disqualification standard is set." As a consequence (and since the majority of challenges are brought in good faith), the challenge threshold should not remain prohibitively high, in an attempt to dissuade dilatory tactics. 
connections between arbitrators, counsel and parties would become less prevalent. ${ }^{1030}$

Such an enlargement of the pool of investment arbitrators is met with profound skepticism by various scholars. They argue that having a small group of adjudicators is a guarantee for their expertise. ${ }^{1031}$ Clearly, arbitrator expertise is an important factor for a fair and effective proceeding - accordingly, the requirement of decision-makers' competence is often cited alongside the requirements of independence and impartiality. ${ }^{1032}$ The correlation of a small circle of professionals and a high level of expertise, however, is by no means self-evident. On the contrary, the substantive quality and fairness of an award, which the requirement of arbitrators' expertise seeks to guarantee, depends on various factors which conflict with a small circle of arbitrators. Diversity is one of those factors. Competition within the arbitration community - based on the quality and fairness of each member - is another one. The independence and impartiality of decision-makers, finally, is the procedural counterpart to the pursuit of high quality output. All of those elements of a proper and legitimate proceeding would be strengthened if the barriers to entry were lowered, along with the threshold for arbitrator challenges.

Expertise itself has many faces. The qualities sought after in an expert arbitrator have substantially changed since the rise of arbitration as a dispute settlement mechanism, ${ }^{1033}$ and parties' expectations further vary depending on the kind of arbitrator concerned (party-appointed or chairperson). Experience in investment arbitration is only one - although certainly an important element of expertise. Thus, it would be wrong to assume that newcomers do not have sufficient skills to sit on a tribunal. For one, the designation as a "newcomer" is relative. Anyone who is appointed to an investment tribunal is highly likely to have substantial expertise to show - either as a commercial arbitrator, as a tribunal secretary or assistant, as a scholar, or as a (former) government official. Each such candidate brings different qualities to the tribunal, which complement those of her or his co-arbitrators. Most importantly, they share one common trait: That their views on legal and political questions

1030 For a similar argumentation in the context of the IBA Guidelines, see Ball, supra note 45, at 51 .

1031 Bishop and Reed, supra note 940, at 412.

1032 ICSID Convention art. 14, para. 1; ICJ-Statute art. 2; DSU art. 8; SCC Arbitration Rules art. 15, para. 1.

1033 See DeZalay and Garth, supra note 1024; Thomas Schultz \& Robert Kovacs, The Rise of a Third Generation of Arbitrators? Fifteen Years after Dezalay and Garth, 28 AR B. INT'L. 161 (2012); Franck, The Role of International Arbitrators, supra note 24, at 1-2. 
are likely to be less cemented than those of seasoned arbitrators, and their ties to other participants in the system less close.

Even if arbitrators' independence and impartiality on the one hand, and their expertise on the other hand, did indeed counteract each other, ${ }^{1034}$ arbitrators' integrity should be given precedence over expertise. In the words of Paulsson:

Great ability may be corrupted; if so, the process is irredeemably flawed. Honest but mediocre arbitrators may fall short of perfection, but still perform adequately. ${ }^{1035}$

The objection that newcomers are more susceptible to conflicts, since their positions in the arbitration community are not safeguarded yet, ${ }^{1036}$ must be dismissed. Of the ICSID challenges examined in Chapter 2, several were directed against some of the oldest and most frequently appointed members of the pool of arbitrators. Others were directed against relative newcomers. Of the three disqualifications which occurred, one concerned Professor Francisco Orrego Vicuña - one of the most central arbitrators in the system. ${ }^{1037}$ The other two were directed against what Franck terms "one-shot-arbitrators." 1038 The case law and empirical information ${ }^{1039}$ are not conclusive as to which group is more susceptible to conflicts of interest. The most realistic answer is that each group - experts and newcomers - is prone to its own kinds of dependencies and biases. The uncertain disqualification threshold has not done much to counteract these enticements. A clearer and stricter standard could be an effective deterrent which would positively influence the parties' and counsel's appointment strategies, as well as the behavior of arbitrators.

In summary, the justifiable doubts standard would be an adequate threshold for the examination of arbitrator challenges under the ICSID Convention. It would lower the entry barriers to the market for arbitrator services and bring about a gradual enlargement of the arbitrator community. Arbitrators' previous familiarities with other participants in the proceeding or with the subject-matter of the dispute would consequently become less prevalent.

1034 See Reinisch and Knahr, supra note 24, at 118.

1035 Paulsson, The IdeA, supra note 22, at 149.

1036 Franck, The Role of International Arbitrators, supra note 24, at 20; Catherine A. Rogers, Regulating International Arbitrators: A Functional Approach to Developing Standards of Conduct, 41 STAN. J. InT'L L. 53, 65 (2005). Mourre, supra note 113.

1037 Burlington.

1038 Blue Bank and Caratube.

1039 Kapeliuk, Collegial Games, supra note 33, at 309-311. 
At the same time, the more realistic threshold would signal a stricter standard of independence and impartiality to seasoned arbitrators as well as newcomers, thereby increasing the chances for ethical behavior. Unmeritorious challenges based on innocuous circumstances would still be dismissed.

The application of a justifiable doubts standard would be possible without an amendment of the Convention. It is not contrary to the wording of Article 57 ICSID Convention, since such an interpretation corresponds with the legislative history and the regulatory purpose of the ICSID Convention. ${ }^{1040}$

\section{4} The Investment Court System Proposed by the European Union

The European Union has been negotiating two major trade and investment agreements with Canada $^{1041}$ (CETA) and the United States ${ }^{1042}$ (TTIP) since 2009 and 2013. While the initial negotiation mandates instructed the European Commission to provide for investor-State dispute settlement in the form of arbitration in the agreements, ${ }^{1043}$ the Commission has reacted to a fiercely critical public debate and opposition to ISDS ${ }^{1044}$ by launching an initiative for the resolution of investor-State disputes in a so-called Investment Court System

1040 See supra Chapter 1, Part 1.2; DAELE, supra note 51, ๆ 5-035.

1041 See Comprehensive Economic and Trade Agreement Between Canada and the European Union and its Member States (CETA) (signed Oct. 30, 2016), http://data.consilium.europa .eu/doc/document/ST-10973-2016-INIT/en/pdf.

1042 The Transatlantic Trade and Investment Partnership, see European Union Proposal for Investment Protection and Resolution of Investment Disputes, http://trade.ec.europa .eu/doclib/docs/2015/november/tradoc_153955.pdf (hereinafter the Eu Proposal). See also Commission Draft Text TTIP - Investment (EU), http://trade.ec.europa.eu/doclib/ docs/2015/september/tradoc_153807.pdf (following the targets set in the Commission Concept Paper (EU) of May 5, 2015, http://trade.ec.europa.eu/doclib/docs/2015/may/ tradoc_153408.PDF).

1043 Council Recommendation (EU) No. 12838/11 of 14 July 2011, at 5, I 26d, available at http:// data.consilium.europa.eu/doc/document/ST-12838-2011-EXT-2/en/pdf; Council Directive No. $11103 / 13$ (EU), at 9, I 23, available at http://data.consilium.europa.eu/doc/document/ ST-11103-2013-DCL-1/en/pdf ("provide for an effective and state-of-the-art investor-to -state dispute settlement mechanism" in the form of "a wide range of arbitration fora as currently available under the Member States' bilateral investment agreements").

1044 See Commission Report (EU), Online Public Consultation on Investment Protection and Investor-to-State Dispute Settlement (ISDS) in the Transatlantic Trade and Investment Partnership Agreement (TTIP), available at http://rade.ec.europa.eu/doclib/docs/2015/ january/tradoc_153044.pdf; European Commission, European Commission Launches Public Online Consultation on Investor Protection in TTip (Mar. 27, 2014), http:// trade.ec.europa.eu/doclib/press/index.cfm?id=1052; see also August Reinisch, The 
(ICS). According to the European Union, ICS is intended to strengthen the general confidence in investor-State dispute settlement. It is therefore "[b]uilt around the same key elements as domestic and international courts."1045 ICS implements several of the reform proposals analyzed in Parts 1 to 3 of this Chapter.

This Part briefly outlines the proposed ICS mechanisms under both CETA and TTIP, and examines whether the European Union's portrayal of ICS as an answer to risks of a lack of independence and impartiality in investor-State arbitration withstands critical scrutiny.

\subsection{Investor-state Dispute Settlement under CETA}

The inclusion of ICS in CETA, as signed at the EU-Canada Summit of October 30, 2016 in Brussels, ${ }^{1046}$ marks a first success of the European Union in its initiative to reform ISDS. Earlier drafts of the agreement had provided for $a d$ hoc investor-State arbitration - as a result of the public consultation on ISDS in TTIP, ${ }^{1047}$ however, these provisions were replaced by ICs. ${ }^{1048}$ CETA will become effective once it is approved by the European Parliament and ratified by all Member States through their respective national procedures. Upon the European Parliament's approval, parts of CETA will be provisionally applied, with the exception of ICS. ${ }^{1049}$

European Union and Investor-State Dispute Settlement: From InvestorState Arbitration to Permanent Investment Court 1 (2016).

1045 Commission Press Release (EU), Commission Proposes New Investment Court System for TTIP and Other EU Trade and Investment Negotiations (Sep. 16, 2015), http://europa.eu/ rapid/press-release_IP-15-5651_en.htm.

1046 See Council Decision (EU) on the Signing on Behalf of the European Union of the Comprehensive Economic and Trade Agreement (CETA) between Canada, of the one Part, and the European Union and its Member States, of the Other Part (Oct 26, 2016), available at http://data.consilium.europa.eu/doc/document/ST-10972-2016-REV-1/en/pdf.

1047 See supra, note 1044.

1048 Remarkably, this shift took place after the end of the negotiations in August 2014, while the text underwent a thorough legal review ("legal scrubbing") until February 2016. See Barrie McKenna, Canada, EU revise trade deal, add investor-state dispute tribunal, The Globe and Mail (Feb. 29, 2016), http://www.theglobeandmail.com/report-on-business/industry-news/the-law-page/ottawa-says-legal-review-of-canada-eu-free-trade-deal-completed/article28946075/ (referencing Todd Weiler, who warns that "[t]he changes could lead to a tribunal that is seldom used," and that "[i]nvestor guarantees in the Canada-EU deal could be 'rendered ineffectual' if the government-appointed arbitrators apply overly conservative interpretations.").

1049 As a novelty on which public debate is not yet finished, ICS was excluded from the scope of provisional application of CETA. It will only be implemented once all Member States conclude their national ratification procedures. Until such time, the details of the system 
Chapter 8 of CETA governs investment and provides for investor-State disputes to be submitted to the Tribunal constituted under Section F. ${ }^{1050}$ The Tribunal will consist of fifteen Members appointed by the CETA Joint Committee, of which five will be nationals of each Contracting Party (Canada and the EU member States, respectively) and five will be nationals of third countries. ${ }^{1051}$ Individual disputes will be handled by divisions of three Tribunal Members one Member from each of the above-mentioned groups - to be chosen on a random and unpredictable rotational basis by the President of the Tribunal. ${ }^{1052}$ In addition to this Tribunal of First Instance, Article 8.28 CETA provides for an Appellate Tribunal, the exact contours of which remain to be carved out. ${ }^{1053}$

As for the requisite qualifications of the Tribunal Members, Article 8.27.4 CETA provides that they shall be jurists of recognized competence or persons who would qualify for judicial office in their respective country. They shall have demonstrated expertise in public international law, preferably in international investment law, international trade law, and in dispute resolution under international trade or investment agreements.

In contrast to these exigent qualification requirements, CETA does not provide for the Tribunal Members to receive a regular salary. Instead, the payment

(i.e. the selection of Tribunal Members, access by smaller businesses, and the appeals mechanism) will be further elaborated. See Council Decision (EU) on the Signing, on Behalf of the Union, and Provisional Application of the Strategic Partnership Agreement between the European Union and its Member States, of the one Part, and Canada, of the Other Part (Sep. 13, 2016), art. 3, available at http://data.consilium.europa.eu/doc/ document/ST-5367-2016-INIT/en/pdf.

1050 See CETA art. 8.18. State-State disputes concerning the interpretation or application of CETA (CETA art. 29.2) and financial services disputes (CETA art. 13.20.1), on the other hand, are resolved through arbitration under Chapter 29. Disagreements regarding the Parties' right to regulate in the fields of labor standards (CETA art. 23.10) and environmental protection (CETA art. 24.15) are examined by Panels of Experts under the respective Chapters. The Code of Conduct established under Chapter 29 and provided for in Annex 29-B to CETA applies to all of these arbitrators and experts, but not to Tribunal Members under Chapter 8, i.e. decision-makers in investment disputes.

1051 CETA art. 8.27.2. A failure of the CETA Joint Committee to appoint all 15 Tribunal Members within 90 days from the submission of a claim would result in the appointment of a division of 3 Members by the ICSID Secretary-General, by random selection from the existing nominations (CETA art. 8.27.17). This continuing involvement of ICSID in what is touted as a new and innovative system is noteworthy.

$105^{2}$ CETA art. 8.27.6 and 7. The President of the Tribunal is drawn by lot from among the third country nationals and appointed for a two-year term (CETA art. 8.27.8).

1053 CETA art. 8.28.7 (leaving issues as fundamental as the number of Appellate Tribunal Members, their remuneration, and the procedures for an appeal open, and to the CETA Joint Committee to decide). 
of a monthly retainer fee ${ }^{1054}$ shall ensure their availability. ${ }^{1055}$ Members who serve on a division constituted to hear a specific claim shall receive fees and expenses in accordance with Administrative and Financial Regulation 14(1) of the ICSID Convention. ${ }^{1056}$ Article 8.27.15 authorizes the CETA Joint Committee to transform the retainer fee and fees and expenses into a regular salary eventually. Until such time, Tribunal Members will be part-time adjudicators, who must pursue some other form of gainful employment to support themselves, at least while they are not serving on a Tribunal division.

With respect to independence and impartiality, CETA contains some widely accepted standard rules, as well as surprisingly far-reaching provisions. In the first category, Article 8.30 CETA provides that Tribunal members may not take instructions from any organization or government with regard to matters related to the dispute, and shall not consider disputes which would create a direct or indirect conflict of interest. ${ }^{1057}$ In the second category, according to Article 8.30.1 CETA, Tribunal Members shall refrain from acting as counsel, as partyappointed experts, or as witnesses in other (pending or new) international investment disputes. The wording of this provision ("upon appointment") implies that dual functions as a Tribunal Member and as a legal advisor and counsel are banned completely, and not just temporarily (i.e. during a Tribunal Member's service on a division).

Under Article 8.30.1 CETA, the IBA Guidelines appear to represent a baseline of independence and impartiality which the Tribunal Members must observe, at least as long as the Contracting Parties have not adopted a specific Code of Conduct for the Tribunal Members. ${ }^{1058}$ Such a Code of Conduct has already been agreed by the Contracting Parties with regard to Chapter 29 arbitrators (i.e. arbitrators which resolve State-State trade and investment disputes), ${ }^{1059}$ and has been widely lauded as an important innovation in investment arbitration. It is not, however, applicable to Chapter 8 Tribunal Members - the Code of Conduct for Members of the Tribunal under CETA Chapter 8 remains to be agreed by the Committee on Services and Investment. ${ }^{1060}$

\footnotetext{
1054 The retainer fee shall be determined by the CETA Joint Committee (CETA art. 8.27.12) and paid equally by Canada and the European Union (CETA art. 8.27.13).

1055 CETA art. 8.27.12.

1056 CETA art. 8.27.14.

1057 CETA art. 8.30.1.

1058 "[The Members of the Tribunal] shall comply with the International Bar Association Guidelines on Conflicts of Interest in International Arbitration or any supplemental rules adopted pursuant to Article 8.44.2." (emphasis added).

1059 See CEta Annex 29-B.

1060 See CETA art. 8.44.2 ("The Committee on Services and Investment shall ... adopt a code of conduct for the Members of the Tribunal to be applied in disputes arising out of this Chapter").
} 
Finally, a welcome improvement in guaranteeing decision-makers' independence and impartiality is the decision of challenges by an outsider, namely the President of the ICJ. ${ }^{1061}$ Where a Tribunal Member's behavior is inconsistent with the specific obligations of independence set out in Article 8.30.1 CETA, she or he may even be removed from the tribunal. ${ }^{1062}$

\subsection{Investor-state Dispute Settlement under TTIP}

A very similar mechanism has been proposed by the European Union in the context of the ongoing negotiations on investment dispute settlement under the TTIP: A standing body of fifteen Judges (five nationals of EU member States, five U.s. nationals and five third country nationals) would be appointed for a six-year term, renewable once. ${ }^{1063}$ Divisions of three Judges, appointed at random and on a rotational basis by the President of the Tribunal (a third country national), would hear individual cases. ${ }^{1064}$ These divisions would always be comprised of one EU, one U.s. and one third country national, with the latter acting as the chair. ${ }^{1065}$ Except for the nomination of their nationals for the standing body of Judges, the Contracting Parties would have no influence over the involvement of any particular Judge in a specific proceeding.

The first instance investment Tribunal would be supplemented by an Appeal Tribunal consisting of six Members, each appointed for a six year term, of whom two would be EU nationals, U.s. nationals, and third country nationals, respectively. ${ }^{1066}$ The Appeal Tribunal would hear appeals in divisions of three Members (an EU member State national, a U.s. national and a third country national). These divisions would be established by the Appeal Tribunal's President (a third country national) in a random and unpredictable way. ${ }^{1067}$ The Appeal Tribunal would ensure that (to quote the Commission) there "could

1061 CETA art. 8.30.2 and 3. Challenges of Chapter 29 arbitrators, by contrast, are decided by the chairman of the panel if a co-arbitrator is challenged, or by the two co-arbitrators if the chairman is challenged. CETA does not provide for a fallback jurisdiction on the challenge of a chairman, in case the two co-arbitrators do not agree. See cEta Annex 29-B, q $23-24$.

1062 CETA art. 8.30.4 (requiring a reasoned recommendation from the President of the Tribunal, or both Contracting Parties, and a decision of the CETA Joint Committee).

1063 EU Proposal art. 9 (2) and (5). The appointing body remains to be determined - the Proposal states that "The [...] Committee shall ... appoint fifteen Judges to the Tribunal".

1064 EU Proposal art. 9 (6) and (7).

1065 EU Proposal art. 9 (6).

1066 EU Proposal art. $10(2)$.

1067 EU Proposal art. 10 (8) and (9). 
be no doubt as to the legal correctness of the decisions of [first instance] tribunals." ${ }^{1068}$

The qualifications required of the First Instance Tribunal Judges and of the Members of the Appeal Tribunal are the same as those under CETA: The adjudicators shall be jurists of recognized competence or persons who would qualify for judicial office (for the highest judicial offices, in the case of Appeal Court Members) in their respective country. A demonstrated expertise in public international law, preferably in international trade and investment law, and in dispute resolution under international trade or investment agreements, is also required. ${ }^{1069}$

As is the case under CETA, a regular salary for First Instance Tribunal Judges and Members of the Appeal Tribunal is not planned. Instead, they shall be paid a monthly retainer fee. For First Instance Tribunal Judges, the European Union proposes a retainer fee which amounts to one third of the retainer fee for WTO Appellate Body members (approximately 2000 Euro), to ensure their availability "at all times and on short notice."1070 For Members of the Appeal Tribunal, a retainer fee roughly equivalent to that of WTO Appellate Body members (7000 Euro per month) was suggested by the EU. ${ }^{1071}$ The actual service on a Tribunal or Appeal Tribunal Division is remunerated with fees and expenses in accordance with Administrative and Financial Regulation 14(1) of the ICSID Convention. ${ }^{1072}$ The various fees may eventually be replaced by a regular salary, if the competent Committee (which remains to be specified) decides so. Only then will the adjudicators serve on a full-time basis and be prohibited from exercising another occupation. ${ }^{1073}$

Certain dual functions are however already banned in the semi-permanent system suggested by the European Union, in line with CETA: Upon appointment, adjudicators shall "refrain from acting as counsel or as party-appointed expert or witness in any pending or new investment protection dispute."1074 In contrast, they may be government officials or receive income from the

1068 European Commission Reading Guide, Draft Text on Investment Protection and Investment Court System in the Transatlantic Trade and Investment Partnership (TTIP) (Sep. 15, 2015), http://europa.eu/rapid/press-release_MEMO-15-5652_en.htm.

1069 EU Proposal art. 9 (4) and 10 (7).

1070 EU Proposal art. 9 (11) and (12).

1071 EU Proposal art. 10 (12).

1072 EU Proposal art. 9 (14). The per diem fee of Appeal Tribunal Members remains to be determined by a Committee which has not yet been specified (see EU Proposal art. $10(12))$.

1073 EU Proposal art. 9 (15) and 10 (14).

1074 EU Proposal art. 11 (1). 
government, as long as they are "otherwise independent of the government"1075 and as long as they do not take instructions from the government regarding the dispute. They may also serve as arbitrators under other international investment agreements, subject to their general obligation of independence and impartiality. 1076

The EU Proposal further contains a Code of Conduct which would apply to both First Instance Tribunal Judges and Members of the Appeal Tribunal. ${ }^{1077}$ It spells out the adjudicators' independence, impartiality and confidentiality obligations and highlights the importance of the appearance of independence and impartiality for the system's integrity. ${ }^{1078}$ While the Code of Conduct describes possible threats to adjudicators' independence and impartiality more illustratively than common Arbitration Rules, its specifications of prohibited behaviors and relationships are not nearly as detailed as the IBA Guidelines. As a result, the Code's application will likely leave a lot of room for interpretation.

Challenges of Judges and Appeal Tribunal Members would be decided by the President of the relevant Tribunal. Requests for the disqualification of one of the Presidents would be decided by the other President, respectively. ${ }^{1079}$ As an ultima ratio measure, adjudicators can be removed from the Tribunals. ${ }^{1080}$

\subsection{ICs - Panacea or Chimera?}

The Investment Court System suggested by the European Union implements several of the reform proposals analyzed in Parts 1 to 3 of this Chapter: It

1075 EU Proposal art. 11 (1) and footnote 6 thereto.

1076 EU Proposal art. 11 (1) ("They shall not participate in the consideration of any disputes that would create a direct or indirect conflict of interest.").

1077 EU Proposal Annex II (Code of Conduct for Members of the Tribunal, the Appeal Tribunal and Mediators).

1078 See EU Proposal Annex II art. 2 ("shall avoid impropriety and the appearance of impropriety"), art. 3 ("shall disclose any ... matter that ... might reasonably create an appearance of impropriety or bias in the proceeding"), art. 5 (1) ("Members must be independent and impartial and avoid creating an appearance of bias or impropriety"), art. 5 (2) ("Members shall not ... incur any obligation or accept any benefit that would ... appear to interfere, with the proper performance of their duties."), art. 5 (3) ("Members shall avoid actions that may create the impression that they are in a position to be influenced by others."), art. 5 (5) ("Members must avoid entering into any relationship or acquiring any financial interest that ... might reasonably create an appearance of impropriety or bias.").

1079 EU Proposal art. $11(2)-(4)$.

1080 EU Proposal art. 11 (5). 
abolishes the party-appointment of adjudicators, completely prohibits certain dual functions, and the Code of Conduct for investment dispute adjudicators proposed in the context of TTIP appears to lower the threshold for challenges. Since these proposals have been examined in detail above, only a few more concrete remarks shall be made at this point.

The abolishment of party-appointments is the most important move away from investor-State arbitration in the Investment Court System: Both CETA and the EU Proposal for ISDS under the TTIP envisage the random appointment of adjudicators to individual divisions, from the respective Tribunals. These Tribunals, in turn, will be set up by Joint Committees under the relevant agreements - political bodies made up of representatives of the Contracting Parties, and co-chaired by their trade ministers. ${ }^{1081}$ It is realistic to surmise that in their appointment of adjudicators to the Tribunals, the Joint Committees are likely to be guided by the appointees' legal, political and ideological views, or that they will rely on important actors in the current ISDS systems, who are able to bring in the necessary expertise and experience. Thus, while delegating the choice of the adjudicators to Joint Committees is certainly an effective way of avoiding appointing party preference on the one hand, it might (on the other hand) at best have an acratic effect and at worst, reinsert nationality bias and re-politicize the system. At the same time, the limitation of eligible adjudicators to fifteen individuals (or even six candidates in the case of the Appeal Tribunal suggested in the context of TTIP) would severely curtail the diversity and expertise on the Tribunals.

Whether the Contracting Parties will be successful in setting up the Tribunals appears unclear: Functionally, the Tribunals are equivalent to closed rosters of candidates, as long as the adjudicators are not employed on a full-time basis, and banned from pursuing other occupations. In other settings, States have so far often failed in their attempts to fill such rosters. ${ }^{1082}$

Another problem is the ban of (certain) dual functions. This measure seems disproportionate, for two reasons: First, the choice of occupations which appointed Tribunal Members, Judges and Appeal Tribunal Members may no longer pursue upon appointment is inconsistent. While adjudicators must

1081 CETA art. 26.1. The Appointing body under the TTIP remains to be specified (Eu Proposal art. $9(2)$ and (5)), but it appears likely that the authority will be delegated to a similarly composed body.

1082 See supra, Part 1.2. Closed rosters were provided for, but not set up as planned in the context of ICSID Convention art. 12, the PCA, NAFTA, and the Iran-United States Claims Tribunal (substitute third-country Members). 
refrain from acting as legal advisors or counsel, ${ }^{1083}$ dual functions as a Tribunal Member / Judge and as a government official are generally admissible, even when they are concurrent. ${ }^{1084}$ The dual function as an adjudicator and as an arbitrator in investment disputes under other international agreements is also permitted in the ICs. Such a dissimilar treatment of different dual functions (in the public and private sector, but also as a counsel in arbitration proceedings and as an arbitrator) calls for an explanation, lest it give rise to reproaches of discrimination, or concerns of a re-politicization of ISDS. How are some of these dual roles more pernicious for the adjudicators' perceived independence and impartiality than others?

Second, the lack of a regular salary of adjudicators implies that their work will be neither full-time, nor exclusive. The modest retainer fee of 2000 Euro per month proposed in the context of TTI ${ }^{1085}$ suggests that appointees to the Tribunals will have to support themselves by pursuing some other gainful employment, while they will not be serving on a division. How this fundamental need will be brought in line with a complete ban of the most common dual function (i.e. consultancy work) remains to be seen. From a practical perspective, the ban is likely to severely limit the pool of sufficiently qualified and experienced decision-makers available. ${ }^{1086}$ The parallel investment arbitration systems, which remain open to the same professionals to bring in their expertise and dispute settlement skills - with close to no limitations on their counsel work, and under much more lucrative conditions - may be given preference by many of the most qualified adjudicators.

The apparent lowering of the challenge threshold to an appearance-based standard in the Code of Conduct proposed in the context of IsDS under the TTIP is very welcome. However, the Code of Conduct is otherwise rather rudimentary and vague, and fails to address various issues which are likely to arise as long as adjudicators do not serve on a full-time basis, and exclusively. Accordingly, there is both a significant potential for a large initial wave of challenges, and a risk that the Code of Conduct's provisions may become

\footnotetext{
1083 CETA art 8.30.1 and EU Proposal art. 11 (1) (both provisions require adjudicators to refrain from acting as counsel, as party-appointed expert, or as witness in other (pending or new) international investment disputes, upon appointment).

1084 See CETA art. 8.30.1, and footnote 8 thereto (clarifying that "the fact that a person receives remuneration from a government does not in itself make that person ineligible"); Eu Proposal art. 11 (1) and footnote 6 thereto. As long as the adjudicators are "otherwise independent of the government" (and, in particular, they do not take instructions from the government regarding the dispute), their dual function appears to be unproblematic.

1085 EU Proposal art. 9 (11) and (12).

1086 See also REINISCH, THE EU AND ISDS, supra note 8, at 25 .
} 
meaningless over time, if they are interpreted too narrowly. A more specific, illustrative Code, in the style of the гва Guidelines, would be preferable.

Such a Code of Conduct could still be drawn up under the CETA, where its enactment was left to the Committee on Services and Investment. ${ }^{1087}$ While it is regrettable that the Code of Conduct under CETA Chapter 8 was not drawn up simultaneously with the Code of Conduct for Chapter 29 arbitrators which would have allowed for structural differences in dispute settlement under Chapters 29 and 8 to be discussed transparently, and provided for accordingly - at least, this omission opens the door for a better, more comprehensive and detailed formulation of the Code.

This leads to the last, and most neuralgic point of ICS: Both CETA and the EU Proposal for ISDS under the TTIP are adamant in terminologically contrasting the Investment Court System and existing investor-State arbitration systems. It is questionable, however, how meaningful the differences between the two systems really are, and how "new and innovative"1088 or "[b]uilt around the same key elements as domestic and international courts"1089 ICS is.

At first blush, the technical terms used in Chapters 8 and 29 of CETA, and in the EU Proposals for ISDS and for State-State arbitration ${ }^{1090}$ under the TTIP, suggest that the dispute settlement mechanism chosen for investment disputes (ICS) is entirely different from arbitration. Investment dispute adjudicators are referred to as Members of the (Appellate / Appeal) Tribunal or Judges, and not as arbitrators; the dispute settlement mechanism is referred to as an Investment Court System, which should eventually be refined and developed

1087 See CETA art. 8.44.2 ("The Committee on Services and Investment shall ... adopt a code of conduct for the Members of the Tribunal to be applied in disputes arising out of this Chapter"). See also Céline Lévesque, CETA's New System for the Resolution of Investment Disputes: What a Difference a Few Months Make, Centre for International Governance Innovation (CIGI) Investor-State Arbitration Commentary Series No. 3 (May 6, 2016), https://www.cigionline.org/publications/cetas-new-system-resolution-investment-disputes-what-difference-few-months-make (explaining the absence of a Code of Conduct for Tribunal Members with the "speed and late stage at which the changes were made to CETA.").

1088 European Commission, European Commission Launches Public Online Consultation on Investor Protection in TTIP (Mar. 27, 2014), http://trade.ec.europa.eu/doclib/press/index .cfm?id=1052.

1089 Commission Press Release (EU), Commission Proposes New Investment Court System for TTIP and Other EU Trade and Investment Negotiations (Sep. 16, 2015), http://europa.eu/ rapid/press-release_IP-15-5651_en.htm.

1090 See European Union Proposal for Dispute Settlement (Government to Government) in TTIP, http://trade.ec.europa.eu/doclib/docs/2015/january/tradoc_153032.pdf. 
into a permanent International Investment Court. ${ }^{1091}$ Upon closer inspection, however, the similarities between the two systems are striking. Under CETA, both the fifteen Tribunal Members under Chapter 8 and the fifteen Candidates on the roster under CETA Chapter 29 are appointed by the CETA Joint Committee. Both bodies are composed of five nationals from each Contracting Party and five nationals from a third State. ${ }^{1092}$ The decision-making divisions (under Chapter 8) or panels (under Chapter 29) are then appointed randomly, by the President of the Tribunal (under Chapter 8) or by the Chair of the CETA Joint Committee, if the Parties fail to agree (under Chapter 29). ${ }^{1093}$ While the remuneration of Chapter 29 arbitrators is not provided for in CETA, it appears likely that there will not be much of a difference between the fees and expenses paid to arbitrators (under Chapter 29) and those owed to Tribunal Members under Chapter 8 of CETA, who (at least initially) will not be permanent salaried employees. ${ }^{1094}$ The same parallels exist in the Eu Proposals for ISDS and for StateState arbitration under the TTIP.

All things considered, the differences in nomenclature should not take away from the fact that Tribunal Members or Judges and arbitrators under the same agreements are probably very similarly positioned. ${ }^{1095}$ While the arbitrators under the agreements are not archetypical ad hoc party-appointed

1091 See Commission Press Release (EU), Commission Proposes New Investment Court System for TTIP and Other EU Trade and Investment Negotiations (Sep. 16, 2015), http:// europa.eu/rapid/press-release_IP-15-5651_en.htm.

1092 CETA art. 8.27.2 and 29.8.1.

1093 CETA art. 8.27.6 and 7, and 29.7.2 and 3. This is also where CETA's most important step away from investor-State arbitration lies: Under Chapter 8, the Parties do not have a right to participate in the selection of their adjudicators.

1094 CETA art. 8.27.12-14. Of course, arbitrators will not receive a retainer fee, in contrast to Tribunal Members and Judges. The suggested retainer fee, however, is so low that it is unlikely to make a difference with regard to the likelihood of conflicts of interest arising from dual functions of the adjudicators.

1095 See also REINISCH, The EU AND ISDS, supra note 8, at 25 ("These tribunals are, in fact, hybrids between courts and arbitral tribunals. They consist of appointed 'judges' serving for renewable six-year terms, but they render 'awards' in order to make them enforceable under the rules of the ICSID Convention or, more likely, under the New York Convention."); Céline Lévesque, The European Commission Proposal for an Investment Court System: Out with the Old, In with the New? 3-4(2016) ("The use of existing arbitration institutions and rules as well as the reliance on international conventions for the enforcement of arbitral awards would seem to indicate that the mechanism is still fundamentally an arbitration one."); Armand De Mestral, CEtA Chapter 8: The Investment Tribunal, Centre for International Governance Innovation (CIGI) Investor-State Arbitration Commentary Series No. 1 (May 2, 2016), https://www .cigionline.org/publications/ceta-chapter-8-investment-tribunal ("The most intriguing question - which will only be resolved as the investment tribunal decides concrete 
decision-makers, the Tribunal Members and Judges in the ICS are not judges on a permanent tribunal (at least not yet), and are therefore similarly exposed to risks of a conflict of interest. In other words, ICS adjudicators are not as immune against potential biases as the $\mathrm{EU}$ terminology implies.

By nature, the Investment Court System is an arbitration system, even if its decision-makers are not appointed by the parties, and certain dual functions are banned. While it could not be referred to as arbitration by the EU, due to a categorical public opposition against investor-State arbitration, elements of arbitration rules and terminology have been interspersed in Chapter 8 of CETA and the EU Proposal for ISDS under the TTIP. ${ }^{1096}$ These references are not accidental, but deliberate and purposeful. They demonstrate the proximity of the Investment Court System to traditional investment arbitration mechanisms. Most importantly, they ensure the execution of awards rendered by the Tribunal divisions under the ICSID Convention and New York Convention. ${ }^{1097}$

From the point of view of democratic legitimacy, the EU would have been better advised to be more transparent with regard to its intentions, and to either devise a truly new and innovative system (built around a permanent court and appellate body), or to base the ISDS chapters of both agreements on existing arbitration systems, and to make incremental but meaningful and effective improvements to those systems.

cases - is whether this institution is actually a form of arbitration or some new form of dispute settlement that is neither judicial nor arbitral?").

1096 See, e.g., CETA art. 8.23.2 and EU Proposal art. 6 (2) (according to which a claim may be submitted under the ICSID Convention and Arbitration Rules, the ICSID Additional Facility Rules, the UnCiTRAL Arbitration Rules, or any other rules on agreement of the disputing parties), CETA art. 8.25.5 and EU Proposal art. 7 (2) (clarifying that the Contracting Parties' consent to arbitration in the agreement, together with the submission of a claim by an investor, shall satisfy the requirements of written consent under the ICSID Convention, the ICsID Additional Facility Rules and the New York Convention), CETA art. 8.27.14 and EU Proposal art. 9 (14) (referring to Administrative and Financial Regulation 14(1) of the ICSID Convention for the determination of Tribunal Members' fees and expenses), CETA art. 8.27.16 and EU Proposal art. 9 (16) and 10 (15) (delegating secretarial services for the Tribunal to the ICSID Secretariat), CETA art. 8.27.17 (authorizing the ICSID SecretaryGeneral to appoint Tribunal Members to divisions, if the CETA Joint Committee fails to make the required appointments in a timely manner).

1097 See CETA art. 8.41 and Eu Proposal art. 30 (referring not to judgments, but to final arbitral awards (under the ICSID Convention, the ICSID Additional Facility Rules, and the UNCITRAL Arbitration Rules), which shall qualify as enforceable awards (relating to claims arising out of a commercial relationship or transaction) under the New York Convention and the ICsid Convention). 